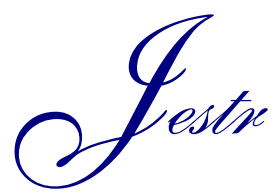

Journal of Engineering Science and Technology Review 9 (4) (2016) 128 - 137

Research Article

\title{
Evaluating Overall Ductility Factor of Steel Frames with Viscoelastic Bracing System
}

\author{
Besan Alagawani $^{1, *}$ and Yousef Al-Qaryouti ${ }^{2}$ \\ ${ }^{1}$ Civil Engineering Department, The University of Jordan, Amman, Jordan \\ ${ }^{2}$ School of Civil Engineering, The University of Queensland, Queensland, Australia
}

Received 12 May 2016; Accepted 2 September 2016.

\begin{abstract}
The primary aim of this study is to evaluate the overall ductility factor of ordinary moment steel frames with viscoelastic bracing system. Similar frames without viscoelastic bracing assessed and compared as well. Linear history analysis of two types with different number of stories and spans lengths is carried out using different earthquake records to determine the elements sizes for the pushover analysis. Pushover analysis has been performed after defining the elements sizes and assigning material nonlinearity to discrete hinge where plastic rotation occurs to beams and columns according to FEMA 356. Such analysis allows evaluating the ductility factor of each building of concern by using the yield and ultimate displacements obtained from the pushover curve. The results showed that the overall ductility factor decreases with increasing the number of stories for all buildings or when the bay length increased. Adding viscoelastic dampers increased the ductility factors for all buildings significantly.
\end{abstract}

Keywords: Overall Ductility Factor, Viscoelastic Bracing, Steel Frames, Nonlinear Analysis, FEMA.

\section{Introduction}

According to statistics that aims to study the frequency and magnitude of earthquakes in each decade, more than 200 earthquakes, which are defined to have a large magnitude when occurs, can happen each decade [1]. This natural action can result in serious damage to human life, economy, and structures in general [2]. However, the number of people that were lost or killed by such natural action is dramatically increasing by time [3].

Life safety has historically been the major concern in earthquake design since earthquakes cause serious loss in human lives [4]. However, based on the statistics, more than three-quarter of cities in the world which have more than 10 million people are living in exposed areas that can be affected by a serious earthquake at any time throughout the year [5].

In general, strength is mainly associated with structural damage control [6]. On the other hand, ductility, low weight, and flexibility are considered to be essential parameters in every structure to resist earthquakes. Because of that, steel structures can efficiently resist earthquakes since they have such proprieties [7].

Deformation under a seismic force will increase significantly only if the structure loses the ability of elasticity, which will lead the stiffness to drop in a serious way [8]. Accordingly, every structure should match the requirements of remaining stable without collapsing when deformation increased. In other words, it can also mean to retain the vertical load carrying capacity [9].

Moreover, the resistance of any structure towards lateral

*E-mail address:besan.alaghwani@gmail.com

ISSN: 1791-2377 @ 2016 Eastern Macedonia and Thrace Institute of Technology. All rights reserved. movement without collapsing is known as ductility. Through the past researches and studies, ductility has followed one strict definition which can be represented as the ratio of ultimate strain to yield strain of the material. Moreover, earthquake engineering shows an obvious focus on understanding the ductility term as well as force reduction factor term to provide the knowledge needed to realize the requirements for achieving ductility capacity to meet ductility demand for designing cost-effective structures that can survive earthquake excitations [10]. Ductility detailing is only needed when the design did not match the requirements of being elastic under serious levels of earthquake vibrations [11].

Feasibility in engineering is just as important as the economic part. Based on that, establishing an elastic structure is costly and hard to apply. However, as long as the structure preserve it is vertical load carrying capacity under high levels of loads that can cause deformation, then it can be taken as a second option that could be applied [12]. Structures sustain and resist earthquake excitations are designed with ultimate strength less than elastic strength demand by two to eight as long as the structure owns properties such as frequency shift, ductility, and energy dissipation capacity [9].

The stiffness in any structural components will only drop once the material has become more compliant. However, the internal forces along with the total base shear that represents the total of the internal shear forces in the entire vertical load carrying element will be considered higher comparing the structure when damaged and in the case remained elastic [13]. The seismic force (elastic force demand) is possibly reduced to the design level (inelastic force demand) through the application of the seismic response modification factor, $\mathrm{R}$, provided that the structure has adequate strength and its elements are ductile enough. This concept has been adopted 
by several seismic design codes in the analysis and design of earthquake resistant structures [14]. However, systems are enabled to undergo low values of deformations just before collapsing by the ductility detailing [15].

Viscoelastic damping system has been adopted for several tall buildings over the world to reduce seismic effects. Major reduction of lateral movements by such system has been gained in those buildings. Recent researches have been conducted and proved that viscoelastic damping system is suitable for seismic resistant structures $[16,17,18,19$, among others $]$.

Overall ductility factors for ordinary moment steel frames equipped with viscoelastic damping system are not given in the building codes such as IBC. The following study will include an assessment of the overall ductility factor without the viscoelastic damping system. For the exact frame, overall ductility factor is evaluated which represents the viscoelastic damping system that is used on the steel ordinary moment frames.

Moreover, buildings with different bay lengths and multi-story will be investigated as factors which will influence the response of the building. Buildings with three-, six-, nine-, twelve-, and fifteen-story will be considered to study the effect of number of stories on the ductility factor along with the effect of span length with five-, seven-, and nine-meter length.

\section{Overall Ductility Factor}

The ductility usually defined as the capacity of the structure to sustain large inelastic deformations without collapse and any major reduction in strength and stiffness [9]. Most of the structures are designed and constructed to behave plastically under severe earthquakes for economy reasons. The response extents of earthquake-induced vibrations are dependent on the energy dissipation level of the structures, which is a function of their capability to absorb and dissipate energy by ductile deformations [9].

The overall ductility factor is the most common indicator of seismic design, is defined as the ratio between ultimate displacement and yield displacement, and represented as following:

$\mu_{\text {overall }}=\frac{\Delta_{\mathrm{u}}}{\Delta_{\mathrm{y}}}$

Where $\Delta_{\mathrm{u}}$ and $\Delta_{\mathrm{y}}$ are displacements at ultimate and yield points, respectively.

For multistory buildings, the maximum and yield displacements that determined the story ductility measured at the roof level to evaluate overall ductility factor [3]. The overall system ductility, $\mu$, can be defined as some weighted average of the story ductility factors, and is calculated by considering a particular pattern of displacement corresponding to the fundamental mode shape or any other combination of mode shapes [20].

The effectiveness of the design approach involving strong column-weak beam concept is still a controversial matter; it will be dangerous to design the structures without taking into account the formation of plastic hinges in columns [21]. Also, nonlinear deformations and formation of plastic zones are most likely to occur in the lower stories, while the walls of the upper stories will behave in the elastic range for multistory frames [22].

\section{Case Study and Analysis Methodology}

\subsection{Case Study and Building Description}

This study will be aiming to use two types of lateral force resisting building system; ordinary moment steel frame system and ordinary moment steel frame with viscoelastic damping system, to calculate overall ductility factor, $\mu$. Steel frame constructions for the study are of three-, six-, nine-, twelve-, and fifteen-story. Also, different bay length effects on ductility factor have been included in the study of five-, seven-, and nine-meter spans length for three story steel frame building.

Most constructions are parts of the ordinary moment steel frame whether it includes viscoelastic damping system or not. Moreover, it should contain both orthogonal directions along with the same floor plan as shown in Fig. 1. They have three bays with $5.0 \mathrm{~m}$ spacing in each horizontal and transverse direction for all stories of the building

As mentioned before, different bay lengths of five-, seven-, and nine-meter for the three-story building have been included. All stories have a height of $3.0 \mathrm{~m}$ each. The applied design live load is $2.0 \mathrm{KN} / \mathrm{m}^{2}$ on all floors while the applied design dead load is $5.8 \mathrm{KN} / \mathrm{m}^{2}$ on all floors. All columns and main beams have steel section of the shape of $\mathrm{H}$-section of different sizes based on linear time history analysis and design of the building of a different number of stories. All secondary beams have steel I-section of different sizes based on linear time history analysis and design of the building of a different number of stories. All steel elements are designed according to AISC360-10 LRFD provisions [23].

The unit weight of steel was applied as $76.8 \mathrm{KN} / \mathrm{m}^{3}$. All steel elements are made of the steel material of Grade 50 that have yield and ultimate strength of $345 \mathrm{Mpa}$ and $448 \mathrm{Mpa}$ respectively. Fig. 1 also shows elevations of ordinary moment steel frame system without viscoelastic dampers of three story building.

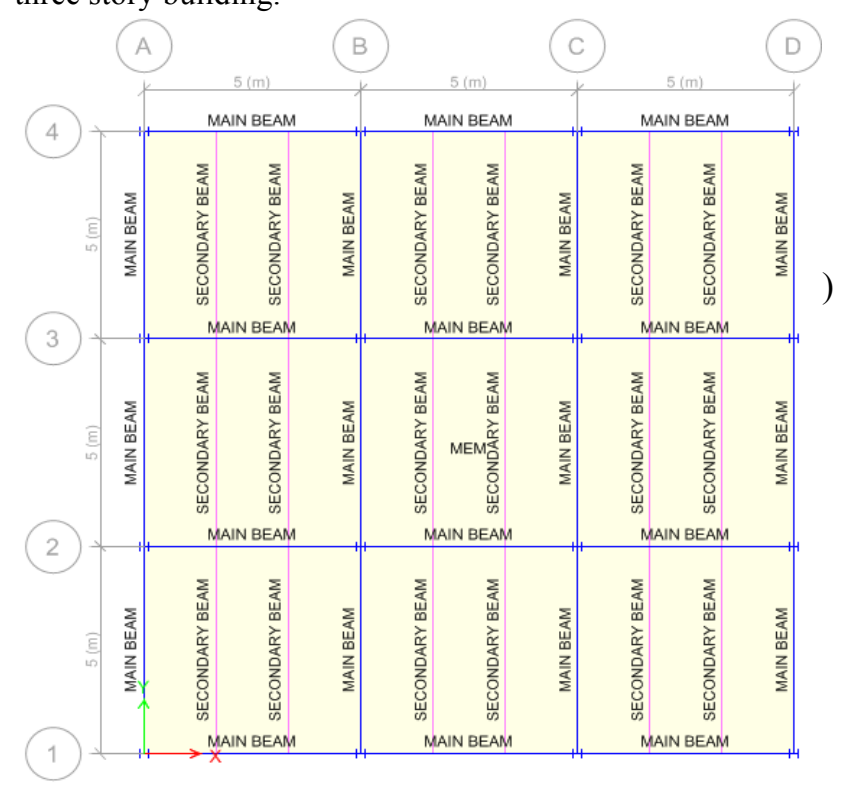




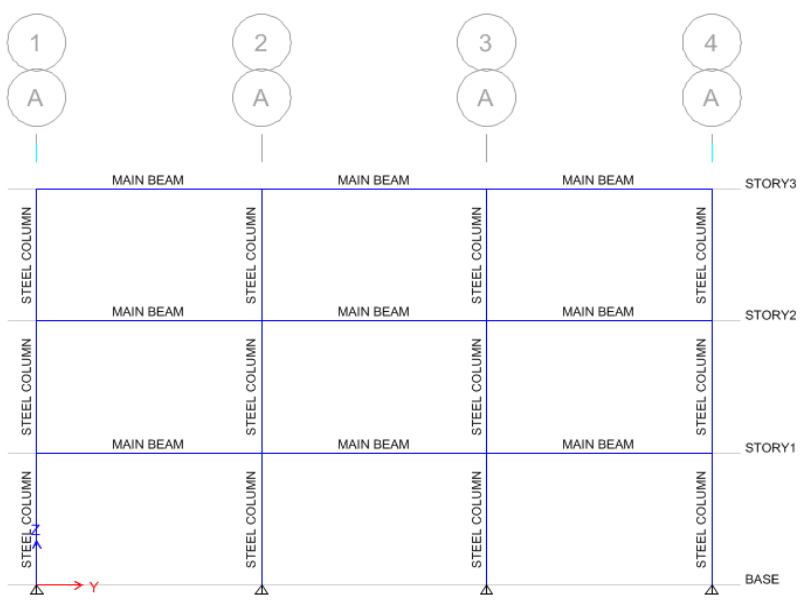

Fig. 1. Plan and Elevation View of the Ordinary Moment Steel Frames Buildings without Viscoelastic Damping System.

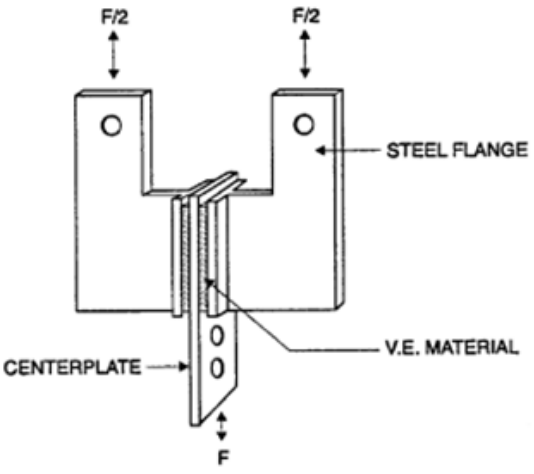

Fig. 2. Viscoelastic Damping Element.

Fig. 3 characterize the viscoelastic dampers that are to be used in the outer frames on every floor in the central bays with the stiffness of $10,000 \mathrm{KN} / \mathrm{m}$ and damping coefficients of 5,000 KN-sec/m. A modern design application defined as ETABS 2013 and using the previous damping factor and the properties of the effective stiffness are used to define the viscoelastic damper (CSI Structural Analysis Program, 2013).
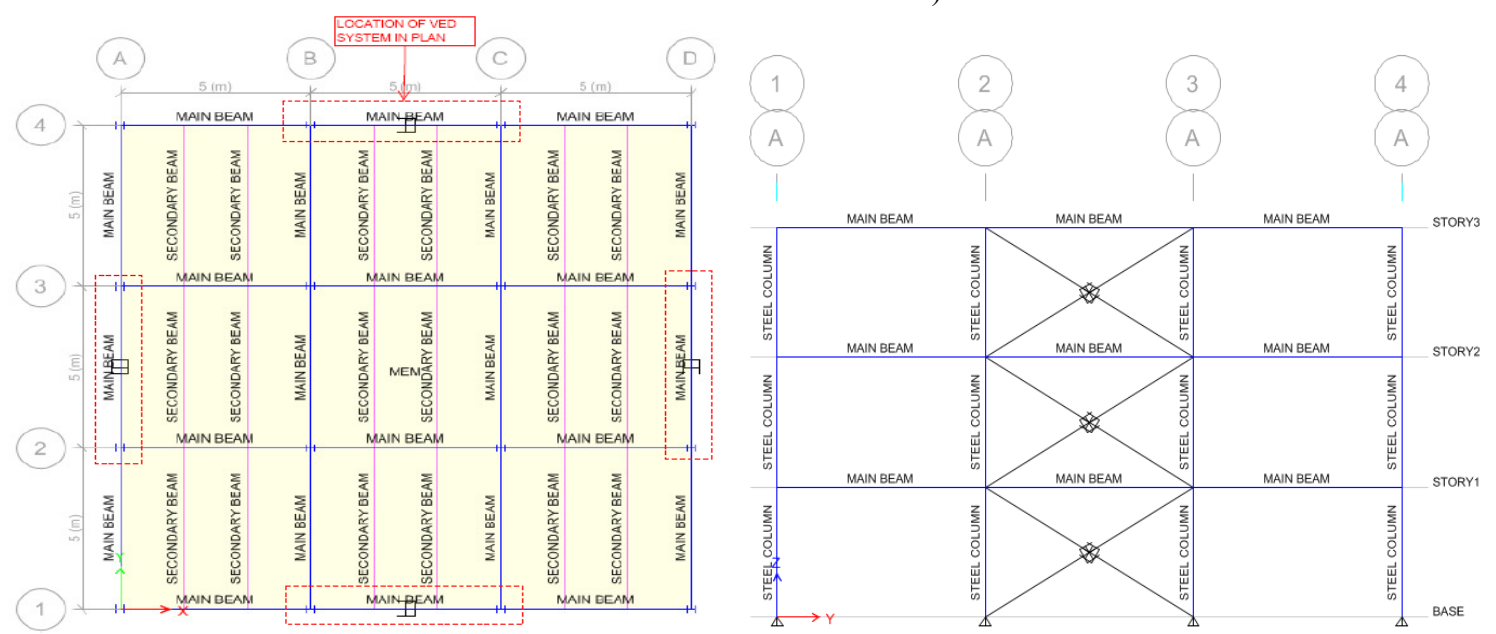

Fig. 3. Viscoelastic Dampers Location in Plan and Elevation of Ordinary Moment Resisting Steel Frame Building in the Outer Frames.

A modern design software application is used to determine the steel section size, deformability and the strength of each element for quality and quantity purposes of the building

(CSI Structural Analysis Program, 2013).

\subsection{Analysis Methodology}

Linear time history analysis and nonlinear static pushover analysis have been carried out using ETABS 2013 in the global X direction to evaluate the overall ductility factor for each building of concern. Different earthquake records have been used in the linear time history to include the variability in ground motion characteristics

Seismic weight including dead load is applied on the frames according to ASCE7-10 section 12.7.2 and used in the linear time history analysis (ASCE7, 2010). Linear time history analysis will be used to evaluate and analysis each building of concern and to determine steel elements sizes for the inelastic pushover analysis. Also, 5\% modal damping ratio will be applied as well. According to AISC360-10, the design of the building will have the following load combinations:

$$
\mathrm{U}=1.4 \mathrm{D}
$$

$$
\mathrm{U}=1.2 \mathrm{D}+1.6 \mathrm{~L}
$$

$$
\mathrm{U}=1.2 \mathrm{D}+1.0 \mathrm{E}+1.0 \mathrm{~L}
$$

$$
\mathrm{U}=0.9 \mathrm{D}+1.0 \mathrm{E}
$$

Where $\mathrm{D}=$ the design dead load, $\mathrm{L}=$ the design live load, and $\mathrm{E}=$ the effect of earthquake forces.

Nonlinear static pushover analysis will use the steel elements sizes that are obtained from the design load combination along with the linear time history analysis. Moreover, the properties of the plastic hinges will be applied along with FEMA 356 at the beams and columns beginnings and ends (FEMA, 1997).

\subsection{Nonlinear Pushover Analysis}

Nonlinear pushover analysis is carried out under constant gravity loads and monotonically increasing horizontal loads and used to obtain the pushover curve that aims to build the global load deformation curve till the failure is reached in the given structure. Moreover, the nonlinear static analysis is used to obtain the single force-displacement curve which is known as the pushover curve; it is also known to be an 
incremental and iterative solution of static equilibrium equations.

Plastic rotation occurs when material nonlinearity is assigned into discrete hinge during the analysis of frame objects (FEMA, 1997). During pushover analysis, many factors are available including P-delta effect, staged construction and link assignment.

ETABS software is used to model the fiber plastic hinges along with plastic deformation that occurs within and act as a discrete point hinge. Also, ETABS is used for builtin default fiber hinge properties for steel elements according to FEMA 356 that require the section to be I or H (CSI Structural Analysis Program, 2013). Moreover, the nonlinear analysis should be performed after the design has been chosen.

\subsection{Seismic Records}

According to California earthquake, 1993, long beach; a group of strong vibration was recorded. Additionally, all over the world and many other places it is worth mentioning that to make future studies by engineers and scientists the motions of earthquakes shall be recorded. Moreover, in the civil engineering, the motions of the structures were studied in details to obtain the seismic codes and to be able to analysis and design a structure that can stand this type of motion.

Different earthquake records are shown in Fig. 4 to 9 six records were used in the time history analysis to include the variability in ground motion characteristics. Additionally, accelerograms that are shown in Fig. 4 through 9 which are also applied on ETABS 2013 are considered as the ground acceleration, where $\ddot{u}_{\mathrm{g}}$ in $\mathrm{cm} / \mathrm{sec} 2$ (Y-axis), and $\Delta \mathrm{t}$ in second (X-axis) (Al-Qaryouti, 2014).

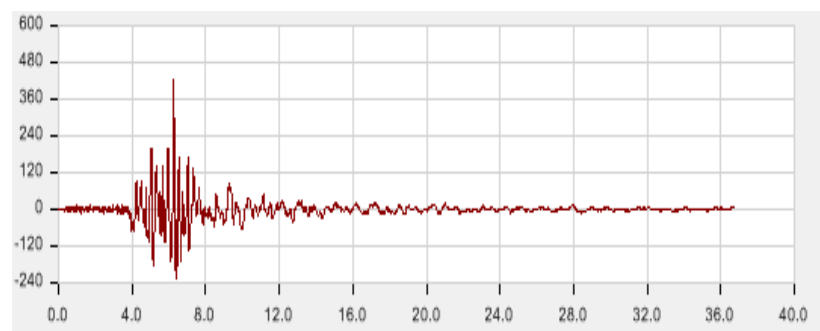

Fig. 4. Parkfield California N85W Earthquake Accelerogram (June 27, 1966).

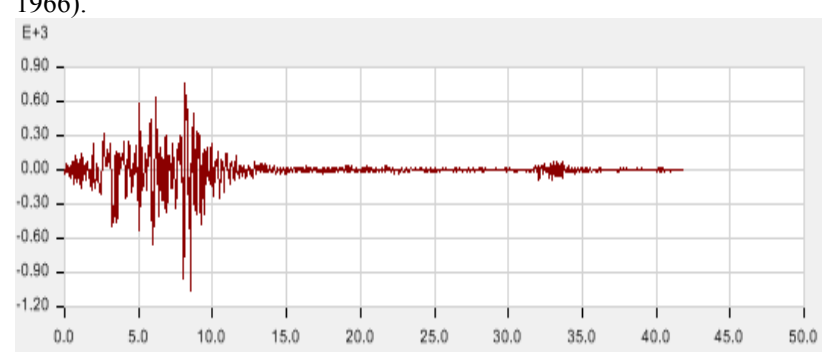

Fig. 5. San Fernando California S74W Earthquake Accelerogram (February 9, 1971).

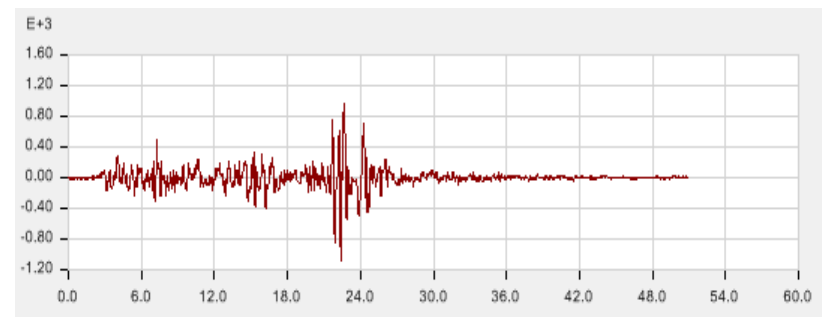

Fig. 6. Nahanni Canada Earthquake Accelerogram (December 23, 1985).

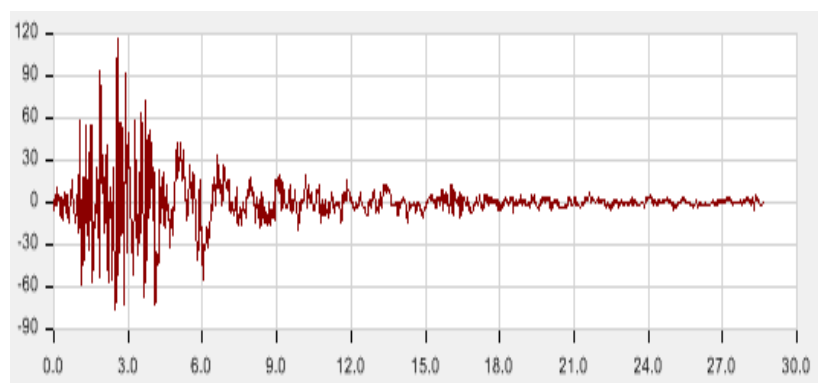

Fig. 7. San Fernando California S38W Earthquake Accelerogram (February 9, 1971).

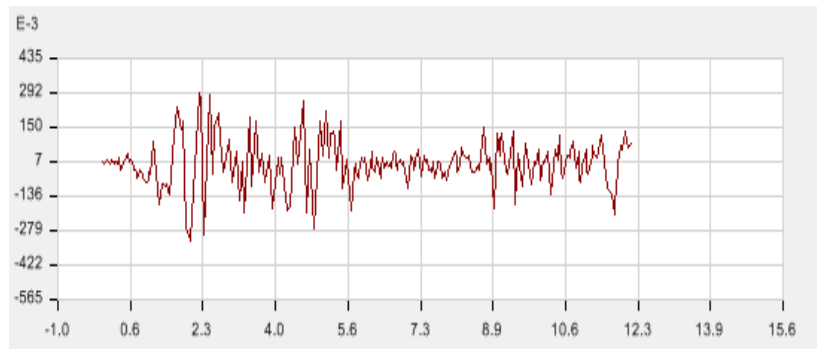

Fig. 8. El Centro (California) N-S Component Earthquake Accelerogram (May 18, 1940).

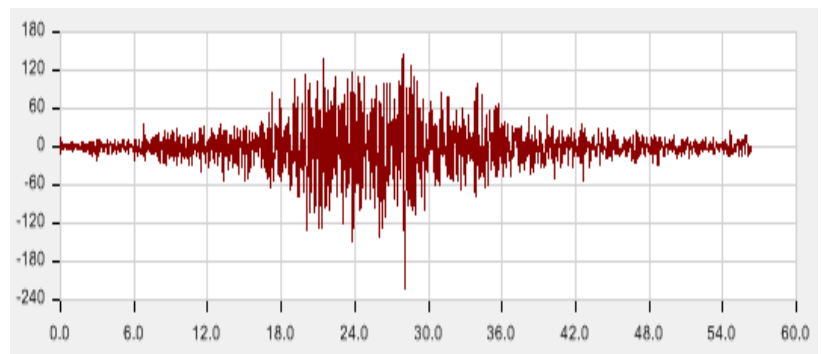

Fig. 9. Near E. Coast of Honshu Japan N00E Earthquake Accelerogram (May 16, 1968).

\section{Results and Discussion}

\subsection{Frame Section Sizes Summary}

Linear time history analysis has been performed using various seismic records to determine the steel frame sections sizes (columns, main beams, secondary beams) so that they can be used in the nonlinear pushover analysis. Tab. 1 and Tab. 2 summarized steel section sizes for each case of concern in the study.

Table 1. Steel Frame Elements Sizes Based on Number of Stories

\begin{tabular}{cccc}
\hline $\begin{array}{c}\text { Number of } \\
\text { Stories }\end{array}$ & Column & Main Beam & $\begin{array}{c}\text { Secondary } \\
\text { Beam }\end{array}$ \\
\hline 3 & HEB200 & HEB200 & IPE200 \\
6 & HEB260 & HEB260 & IPE200 \\
9 & HEB280 & HEB280 & IPE200 \\
12 & HEB340 & HEB340 & IPE200 \\
15 & HEB400 & HEB400 & IPE200 \\
\hline
\end{tabular}

Table 2. Steel Frame Elements Sizes Based on Span Length for 3-Story Building

\begin{tabular}{cccc}
\hline Span Length & Column & Main Beam & $\begin{array}{c}\text { Secondary } \\
\text { Beam }\end{array}$ \\
\hline 5 & HEB200 & HEB200 & IPE200 \\
7 & HEB240 & HEB240 & IPE240 \\
9 & HEB340 & HEB340 & IPE300 \\
\hline
\end{tabular}




\subsection{Static Pushover Curve}

Static pushover analysis utilizes the static pushover curve which is defined as a single force-displacement curve to evaluate the overall ductility factor of the system. It consists of (X-axis) which is named as monitored top roof displacement and (Y-axis) which is named as the base shear force according to ETABS 2013 software. As mentioned before, obtaining the yield and ultimate force and displacement from the pushover curve can be useful to evaluate the overall system ductility factor.

As mentioned before, ETABS 2013 software gives the static pushover curves of the buildings by performing a static pushover analysis. Moreover, by reaching the first critical yield displacement point at the curve the first plastic hinge will be formed in the structure of concern.

Fig. 10 shows static pushover curves of three-, six-, nine, twelve-, and fifteen-story of ordinary moment steel frame buildings without viscoelastic dampers, while Fig. 11 shows static pushover curves of three-, six-, nine-, twelve-, and fifteen-story of ordinary moment steel frame buildings with viscoelastic dampers.
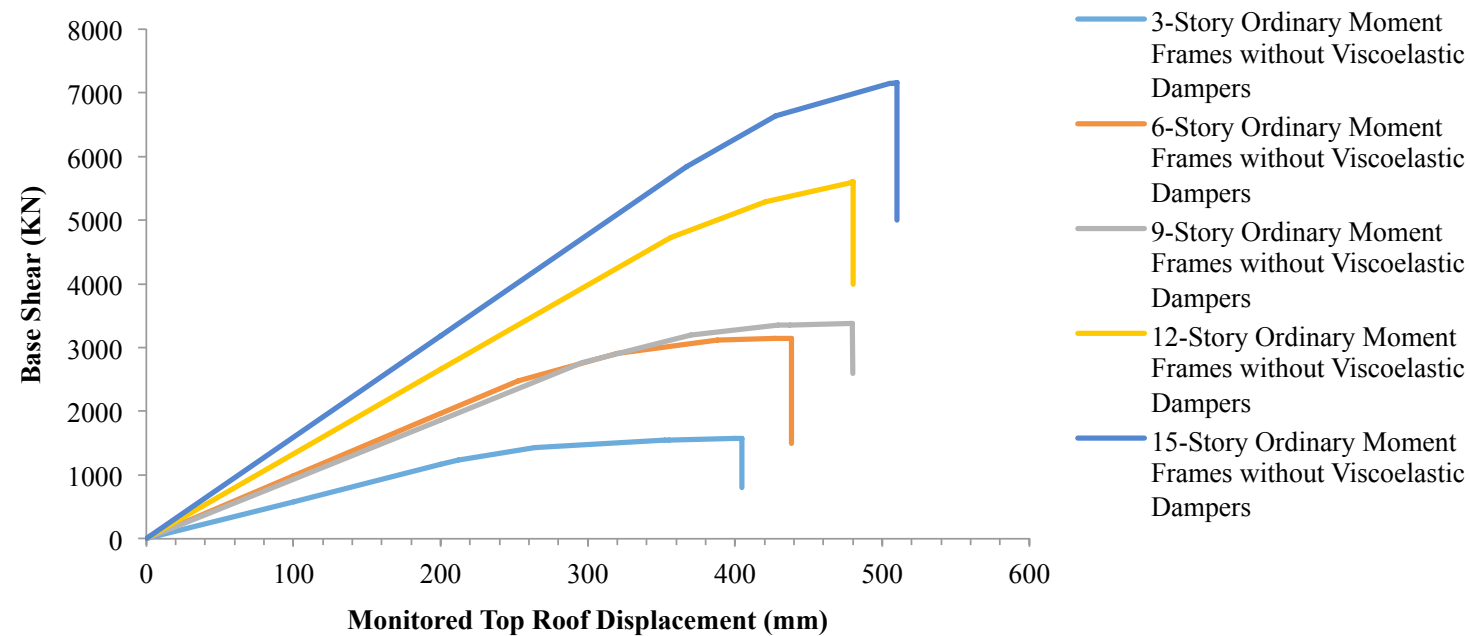

Fig. 10. Static Pushover Curve of Three-, Six-, Nine-, Twelve-, and Fifteen-Story Ordinary Moment Frame Building without Viscoelastic Dampers.

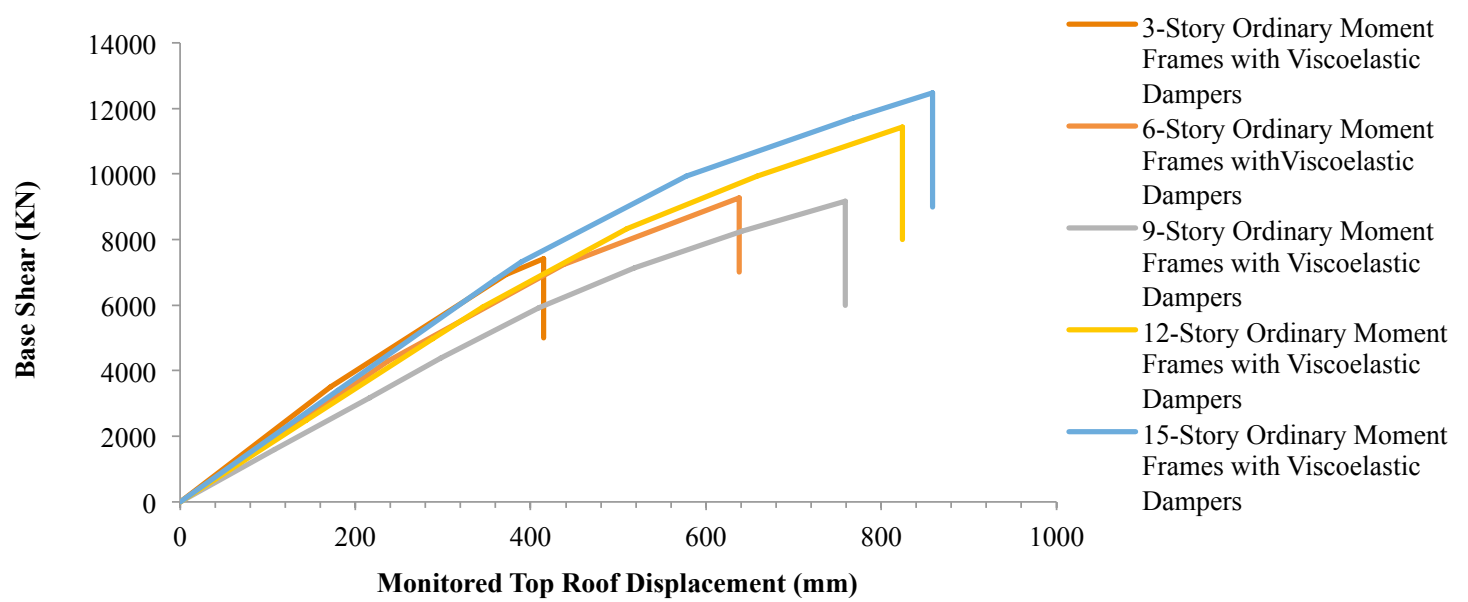

Fig. 11. Static Pushover Curve of Three-, Six-, Nine-, Twelve-, and Fifteen-Story Ordinary Moment Frame Building with Viscoelastic Dampers.

Fig. 12 shows static pushover curves of five-, seven-, and nine-meter spans length of ordinary moment steel frame buildings without viscoelastic dampers, while Fig. 13 shows static pushover curves of five-, seven-, and nine-meter spans length of ordinary moment steel frame buildings with viscoelastic dampers. 


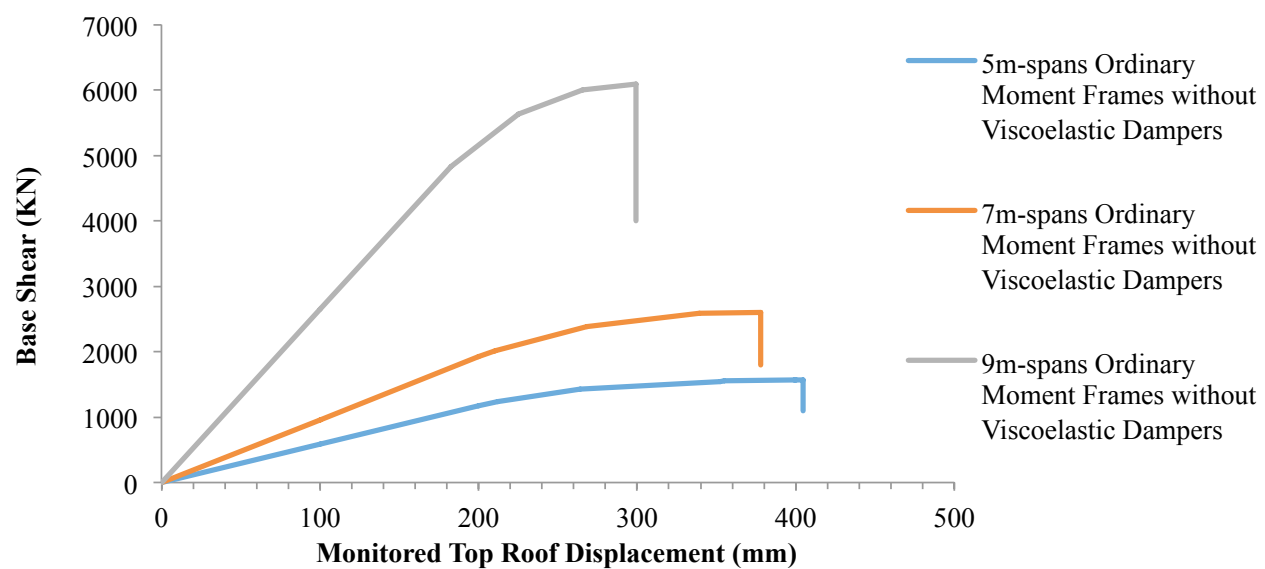

Fig. 12. Static Pushover Curve of Five-, Seven-, and Nine-meter Spans Length Ordinary Moment Frame Building without Viscoelastic Dampers.

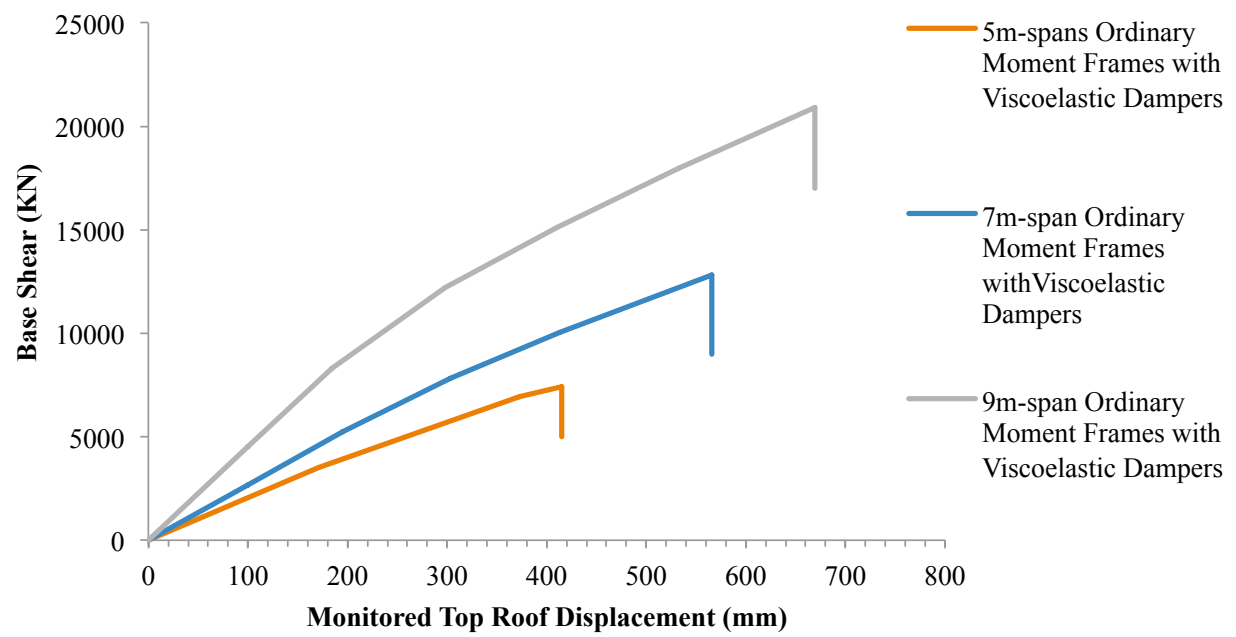

Fig. 13: Static Pushover Curve of Five-, Seven-, and Nine-meter Spans Length Ordinary Moment Frame Building with Viscoelastic Dampers.

\subsection{Overall Ductility Factor}

The overall system ductility factor, $\mu$, the study target factor, can be easily characterized as the ultimate displacement divided by the corresponding displacement of the top roof when yield occur $(\Delta \mathrm{u} / \Delta \mathrm{y})$. These two parameters can be got from static pushover curve. The ductility factor is likewise called as deflection amplification factor according to ASCE7-10 [25]. It is important to mention that yield displacement has been measured and determined based on the formation of the first plastic hinge in the structure.

Tab. 3 shows overall ductility factor of three-, six-, nine-, twelve-, and fifteen-story ordinary moment steel frame building without viscoelastic damping system as the first case. Moreover, Fig. 14 shows that the overall ductility factor is decreased as the number of stories increased. Such result can be related to the increasing of axial compressive force on columns by increasing number of stories which has an effect on decreasing overall ductility factor. According to ASCE 7-10, deflection amplification factor is equal to 3.0 for the buildings of concern which is higher than the results that make it a very conservative value.

Table 3. Overall Ductility Factor of Three-, Six-, Nine-, Twelve-, and Fifteen-Story Ordinary Moment Steel Frame Buildings without Viscoelastic Dampers.

\begin{tabular}{c|c|c|c}
\hline $\begin{array}{c}\text { No. of } \\
\text { Storie } \\
\mathbf{S}\end{array}$ & $\begin{array}{c}\text { Yield } \\
\text { Displacement } \\
\boldsymbol{\Delta}_{\mathbf{y}}(\mathbf{m m})\end{array}$ & $\begin{array}{c}\text { Ultimate } \\
\text { Displacement } \\
\boldsymbol{\Delta}_{\mathbf{u}}(\mathbf{m m})\end{array}$ & $\begin{array}{c}\text { Overall } \\
\text { Ductility } \\
\text { Factor } \boldsymbol{\mu}\end{array}$ \\
\hline 3 & 212 & 404.64 & 1.91 \\
\hline
\end{tabular}

\begin{tabular}{c|c|c|c}
\hline 6 & 252.5 & 438.50 & 1.74 \\
9 & 296.1 & 479.60 & 1.62 \\
12 & 356 & 485.00 & 1.36 \\
15 & 427 & 510.00 & 1.19 \\
\hline
\end{tabular}

Tab. 4 shows overall ductility factor of three-, six-, nine-, twelve-, and fifteen-story ordinary moment steel frame building with viscoelastic damping system as the second case. Moreover, Fig. 14 shows as a result that the overall ductility factor is decreased as the number of stories increased.

Table 4. Overall Ductility Factor of Three-, Six-, Nine-, Twelve-, and Fifteen-Story Ordinary Moment Steel Frame Buildings with Viscoelastic Dampers.

\begin{tabular}{c|c|c|c}
\hline $\begin{array}{c}\text { No. of } \\
\text { Storie } \\
\mathbf{s}\end{array}$ & $\begin{array}{c}\text { Yield } \\
\text { Displacement } \\
\boldsymbol{\Delta}_{\mathbf{y}}(\mathbf{m m})\end{array}$ & $\begin{array}{c}\text { Ultimate } \\
\text { Displacement } \\
\boldsymbol{\Delta}_{\mathbf{u}}(\mathbf{m m})\end{array}$ & $\begin{array}{c}\text { Overall } \\
\text { Ductility } \\
\text { Factor } \boldsymbol{\mu}\end{array}$ \\
\hline 3 & 155.20 & 415.10 & 2.67 \\
6 & 242.88 & 637.90 & 2.63 \\
9 & 302.82 & 759.00 & 2.51 \\
12 & 340.58 & 824.10 & 2.42 \\
15 & 377.91 & 858.50 & 2.27 \\
\hline
\end{tabular}

The effect of adding viscoelastic dampers to the system can be observed in Fig. 14 by comparing overall ductility 
factors of three-, six-, nine-, twelve-, and fifteen-story ordinary moment steel frames with and without viscoelastic dampers. The results show that higher overall ductility factors obtained when the viscoelastic damping system added. Such result can be related to the increasing of building stiffness by adding viscoelastic damping system which has an effect on increasing overall ductility factor.

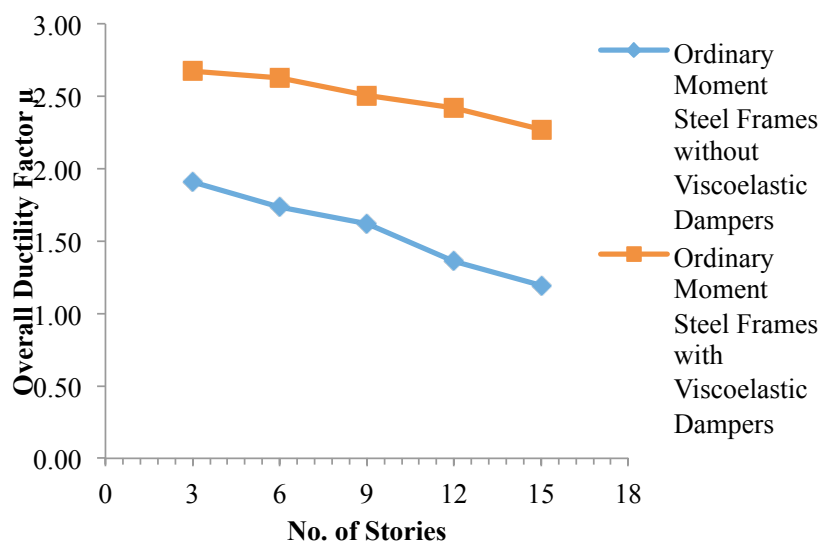

Fig. 14. Overall Ductility Factor of Three-, Six-, Nine-, Twelve-, and Fifteen-Story Ordinary Moment Steel Frame Buildings with and without Viscoelastic Dampers.

Tab. 5 shows overall ductility factor of five-, seven-, and nine-meter spans length for three stories ordinary moment steel frame building without viscoelastic damping system as the first case. Moreover, Fig. 17 shows as a result that the overall ductility factor is decreased as the length of spans increased. Such result can be related to the increasing of axial compressive force on columns by increasing bay length which has an effect on decreasing overall ductility factor.

Table 5. Overall Ductility Factor of Five-, Seven-, and Nine-meter Spans Length Ordinary Moment Steel Frame Buildings without Viscoelastic Dampers.

\begin{tabular}{c|c|c|c}
\hline $\begin{array}{c}\text { Span } \\
\text { Length } \\
(\mathbf{m})\end{array}$ & $\begin{array}{c}\text { Yield } \\
\text { Displacement } \\
\boldsymbol{\Delta}_{\mathbf{y}}(\mathbf{m m})\end{array}$ & $\begin{array}{c}\text { Ultimate } \\
\text { Displacement } \\
\boldsymbol{\Delta}_{\mathbf{u}}(\mathbf{m m})\end{array}$ & $\begin{array}{c}\text { Overall } \\
\text { Ductility } \\
\text { Factor } \boldsymbol{\mu}\end{array}$ \\
\hline 5 & 212 & 404.64 & 1.91 \\
7 & 210.3 & 380.60 & 1.81 \\
9 & 182.5 & 299.30 & 1.64 \\
\hline
\end{tabular}

Tab. 6 shows overall ductility factor of five-, seven-, and nine-meter spans length for three stories ordinary moment steel frame building with viscoelastic damping system as the second case. Moreover, Fig. 17 shows as a result that the overall ductility factor is decreased as the length of spans increased.

Table 6. Overall Ductility Factor of Five-, Seven-, and Nine-meter Spans Length Ordinary Moment Steel Frame Buildings with Viscoelastic Dampers.

\begin{tabular}{c|c|c|c}
\hline $\begin{array}{c}\text { Span } \\
\text { Length } \\
(\mathbf{m})\end{array}$ & $\begin{array}{c}\text { Yield } \\
\text { Displacement } \\
\boldsymbol{\Delta}_{\mathbf{v}}(\mathbf{m m})\end{array}$ & $\begin{array}{c}\text { Ultimate } \\
\text { Displacement } \\
\boldsymbol{\Delta}_{\mathbf{u}}(\mathbf{m m})\end{array}$ & $\begin{array}{c}\text { Overall } \\
\text { Ductility } \\
\text { Factor } \boldsymbol{\mu}\end{array}$ \\
\hline 5 & 155.2 & 415.10 & 2.67 \\
7 & 247.61 & 565.80 & 2.29 \\
9 & 303.73 & 669.30 & 2.20 \\
\hline
\end{tabular}

The effect of adding viscoelastic dampers to the system can be observed in Fig. 15 by comparing overall ductility factors of five-, seven-, and nine-meter spans length for three stories ordinary steel moment frame building with and without viscoelastic dampers. The results show that higher overall ductility factors obtained when the viscoelastic damping system added. Such result can be related to the increasing of building stiffness by adding viscoelastic damping system which has an effect on increasing overall ductility factor.

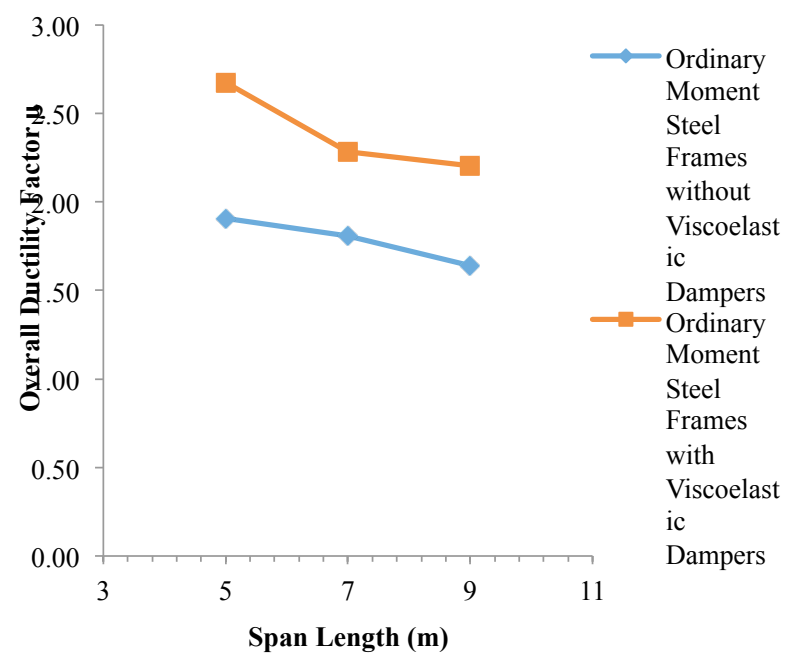

Fig. 15. Overall Ductility Factor Five-, Seven-, and Nine-meter Spans Length Ordinary Moment Steel Frame Buildings with and without Viscoelastic Dampers.

\subsection{Elastic Building Displacement Comparison}

Dynamic linear time history analysis was used to evaluate elastic building displacements, $\Delta_{\mathrm{e}}$, at the rooftop for all the types. Tab. 7 presents the values of elastic displacements for 3-, 6-, 9-, 12-, and 15-story buildings with and without viscoelastic dampers and then plotted in Fig. 16. As a result, increasing the number of stories increases elastic displacements for ordinary moment steel frames and adding viscoelastic dampers to ordinary moment steel frames decreased the elastic displacement for all story buildings significantly because of the viscoelastic dampers increasing the building stiffness which will decrease the lateral elastic movements.

Table 7. Elastic displacement for Three-, Six-, Nine-, Twelve-, and Fifteen-Story Ordinary Moment Steel Frame Buildings with and without Viscoelastic Dampers.

\begin{tabular}{c|c|c}
$\begin{array}{c}\text { No. } \\
\text { of } \\
\begin{array}{c}\text { Stori } \\
\text { es }\end{array}\end{array}$ & $\begin{array}{c}\boldsymbol{\Delta}_{\mathbf{e}} \text { for Ordinary } \\
\text { Moment Frames } \\
\text { without Viscoelastic } \\
\text { Dampers } \\
(\mathbf{m m})\end{array}$ & $\begin{array}{c}\boldsymbol{\Delta}_{\mathbf{e}} \text { for Ordinary } \\
\text { Moment Frames with } \\
\text { Viscoelastic Dampers } \\
(\mathbf{m m})\end{array}$ \\
\hline 3 & 128 & 11 \\
6 & 138.3 & 23.1 \\
9 & 155.6 & 45.8 \\
12 & 167.1 & 60.7 \\
15 & 186.9 & 78.6 \\
\hline
\end{tabular}




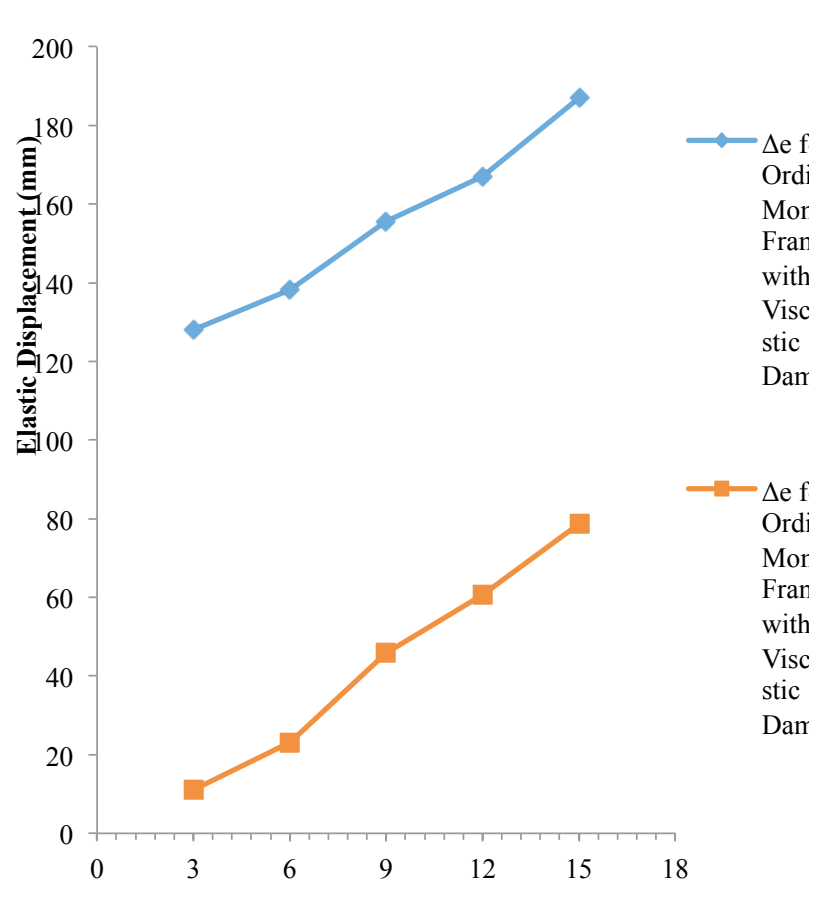

No. of Stories

Fig. 16. Comparison of Elastic Displacement for Three-, Six-, Nine-, Twelve-, and Fifteen-Story Ordinary Moment Steel Frame Buildings with and without Viscoelastic Dampers.

Tab. 8 presents the values of elastic displacements for 5-, 7-, and 9-meter spans length for three story buildings with and without viscoelastic dampers and then plotted in Fig. 17. As a result, increasing the number of stories increases elastic displacements for ordinary moment steel frames and adding viscoelastic dampers to ordinary moment steel frames decreased significantly elastic displacement for all spans length.

Table 8: Elastic displacement for Five-, Seven-, and Ninemeter Spans Length Ordinary Moment Steel Frame Buildings with Viscoelastic Dampers.

\begin{tabular}{c|c|c}
$\begin{array}{c}\text { Lengt } \\
\text { h of } \\
\text { Spans }\end{array}$ & $\begin{array}{c}\boldsymbol{\Delta}_{\mathrm{e}} \text { for Ordinary } \\
\text { Moment Frames } \\
\text { without Viscoelastic } \\
\text { Dampers } \\
\text { (mm) }\end{array}$ & $\begin{array}{c}\boldsymbol{\Delta}_{\mathrm{e}} \text { for Ordinary } \\
\text { Moment Frames with } \\
\text { Viscoelastic Dampers } \\
(\mathbf{m m})\end{array}$ \\
\hline 5 & 128 & 11 \\
7 & 101.9 & 14.8 \\
9 & 83.9 & 15.3 \\
\hline
\end{tabular}

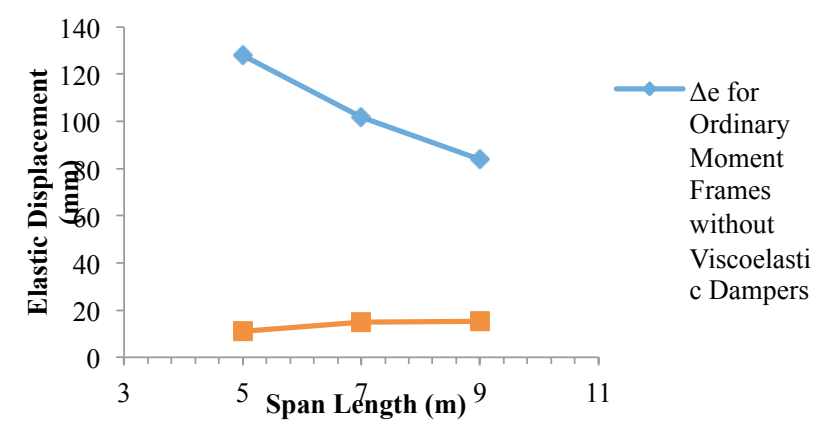

Fig. 17. Comparison of Elastic Displacement for Five-, Seven-, and Nine-meter Spans Length Ordinary Moment Steel Frame Buildings with and without Viscoelastic Dampers.

\subsection{Fundamental Structural Period Comparison}

Fundamental Structural Period, $\mathrm{T}_{\mathrm{n}}$, is a main dynamic characteristic of the earthquake which its evaluation used to estimate the seismic response, so it is important to be mentioned in this section of the study. It can be obtained from the equation $2 \pi \sqrt{\mathrm{M} / \mathrm{K}}$ for a single degree of freedom system as the time needed to complete one cycle and mainly dependent on mass and stiffness, whereas the stiffness $\mathrm{K}$ is affected by nonstructural elements, which are usually not considered in the analysis, the mass $\mathrm{M}$ is simply a random quantity that depends on the occupancy of the structure at the time of the excitations.

Numerous simple and basic relationships have been hardly established to calculate and evaluate the fundamental period of structures. According to ASCE7-10 section 12.8.2.1, the approximate fundamental period of any given structure that depends on the building height is the following equation:

$$
\mathrm{T}_{\mathrm{a}}=\mathrm{C}_{\mathrm{t}} \mathrm{h}_{\mathrm{n}}^{\mathrm{x}}
$$

Where $C_{t}$ and $x$ are Coefficients from ASCE7-10 Table 12.8-2, and $h_{n}$ is the Total height of the building in meters.

Alternatively, for concrete and steel moment frames in buildings that are more than 12 stories high with a minimum story height of $3 \mathrm{~m}(10 \mathrm{ft})$, the approximate period may be estimated as a function of the number of stories, $\mathrm{N}$, as $\mathrm{T}=0.1 \mathrm{~N}$.

Dynamic linear time history analysis was used to evaluate Natural period of structure, $T_{n}$. Tab. 9 through Tab. 12 present the values of the natural structural period with the two equations mentioned before given in ASCE7-10. As a result, the natural periods of the structure are less than the two others for a number of stories case while it is more than approximate periods for spans length case.

Table 9. Structural Period of Three-, Six-, Nine-, Twelve-, and Fifteen-Story Ordinary Moment Steel Frame Buildings without Viscoelastic Dampers.

\begin{tabular}{c|c|c|c}
\hline $\begin{array}{c}\text { No. of } \\
\text { Stories }\end{array}$ & $\begin{array}{c}\text { Natural } \\
\text { Period } \mathbf{T}_{\mathbf{n}} \\
\text { (second) }\end{array}$ & $\begin{array}{c}\mathbf{T}_{\mathbf{a}} \text { using Eq. 6 } \\
\text { (second) }\end{array}$ & $\begin{array}{c}\mathbf{T}_{\mathbf{a}}=\mathbf{0 . 1 N} \\
\text { (second) }\end{array}$ \\
\hline 3 & 1.032 & 0.42 & 0.3 \\
6 & 1.15 & 0.73 & 0.6 \\
9 & 1.3 & 1.01 & 0.9 \\
12 & 1.441 & 1.27 & 1.2 \\
15 & 1.489 & 1.52 & 1.5 \\
\hline
\end{tabular}

Table 10. Structural Period of Three-, Six-, Nine-, Twelve-, and Fifteen-Story Ordinary Moment Steel Frame Buildings with Viscoelastic Dampers.

\begin{tabular}{c|c|c|c}
\hline $\begin{array}{c}\text { No. of } \\
\text { Stories }\end{array}$ & $\begin{array}{c}\text { Natural } \\
\text { Period T } \\
\text { (second) }\end{array}$ & $\begin{array}{c}\text { Ta using Eq. 6 } \\
\text { (second) }\end{array}$ & $\begin{array}{c}\text { Ta=0.1N } \\
\text { (second) }\end{array}$ \\
\hline 3 & 0.545 & 0.42 & 0.3 \\
6 & 0.839 & 0.73 & 0.6 \\
9 & 1.1 & 1.01 & 0.9 \\
12 & 1.257 & 1.27 & 1.2 \\
15 & 1.363 & 1.52 & 1.5 \\
\hline
\end{tabular}

A comparison of natural period of structure for three-, six-, nine-, twelve-, and fifteen-story ordinary moment steel frame buildings with and without Viscoelastic Dampers is 
shown in Fig. 18. It results that as increasing the number of stories the natural period of structure for ordinary moment steel frames increased and by adding viscoelastic dampers to ordinary moment frames the natural period of structure decreased.

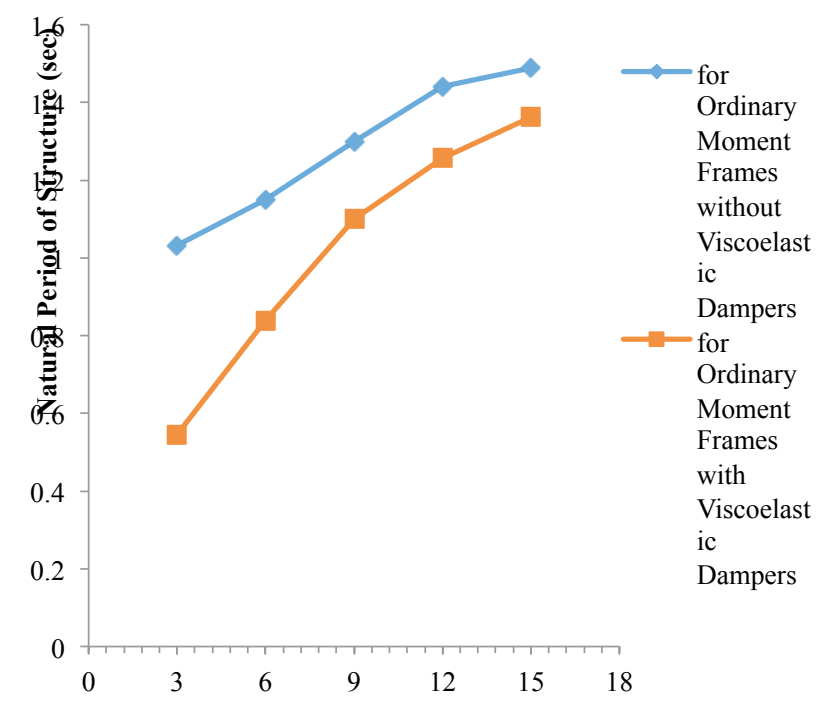

No. of Stories

Fig. 18. Comparison of Natural Period of Structure for Three-, Six-, Nine-, Twelve-, and Fifteen-Story Ordinary Moment Steel Frame Buildings with and without Viscoelastic Dampers.

Table 11. Structural Period of Five-, Seven-, and Ninemeter Spans Length Ordinary Moment Steel Frame Buildings without Viscoelastic Dampers.

\begin{tabular}{c|c|c|c}
\hline $\begin{array}{c}\text { Length } \\
\text { of Spans }\end{array}$ & $\begin{array}{c}\text { Natural } \\
\text { Period Tn } \\
\text { (second) }\end{array}$ & $\begin{array}{c}\text { Ta using } \\
\text { Equation 4.1 } \\
\text { (second) }\end{array}$ & $\begin{array}{c}\text { Ta }=\mathbf{0 . 1 N} \\
\text { (second) }\end{array}$ \\
\hline 5 & 1.032 & 0.42 & 0.3 \\
7 & 1.121 & 0.42 & 0.3 \\
9 & 1.251 & 0.42 & 0.3 \\
\hline
\end{tabular}

Table 12. Structural Period of Five-, Seven-, and Ninemeter Spans Length Ordinary Moment Steel Frame Buildings with Viscoelastic Dampers.

\begin{tabular}{c|c|c|c}
\hline $\begin{array}{c}\text { Length } \\
\text { of Spans }\end{array}$ & $\begin{array}{c}\text { Natural } \\
\text { Period Tn } \\
\text { (second) }\end{array}$ & $\begin{array}{c}\text { Ta using } \\
\text { Equation 4.1 } \\
\text { (second) }\end{array}$ & $\begin{array}{c}\text { Ta= 0.1N } \\
\text { (second) }\end{array}$ \\
\hline 5 & 0.545 & 0.42 & 0.3 \\
7 & 0.668 & 0.42 & 0.3 \\
9 & 0.68 & 0.42 & 0.3 \\
\hline
\end{tabular}

A comparison of natural period of structure for five-, seven-, and nine-meter spans length ordinary moment steel frame buildings with and without Viscoelastic Dampers is shown in Fig. 19. It results that as increasing the length of spans the natural period of structure for ordinary moment steel frames increased and by adding viscoelastic dampers to ordinary moment frames the natural period of structure decreased.

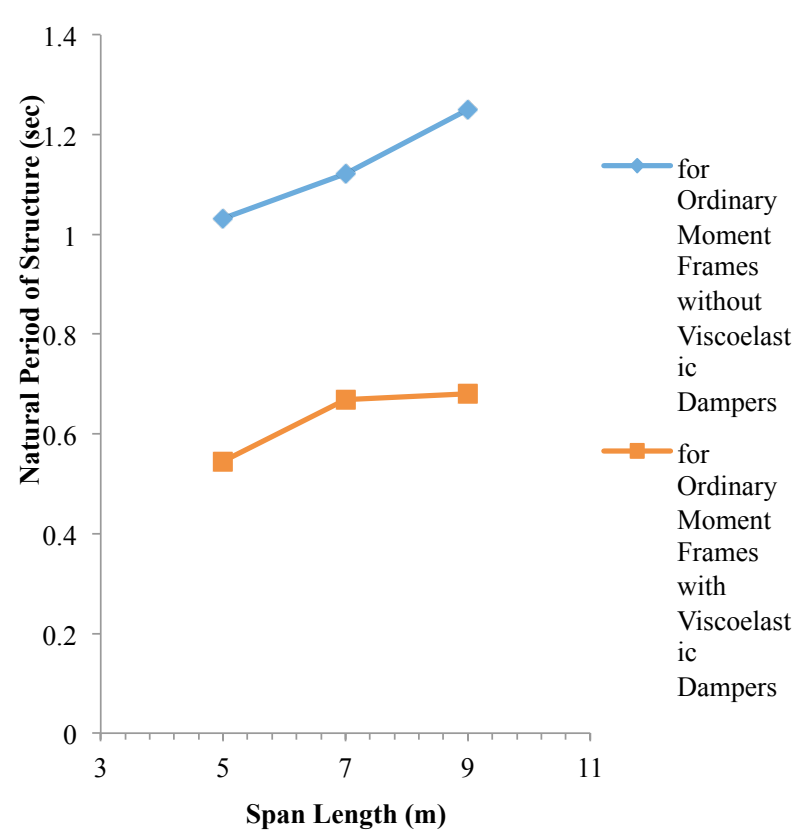

Fig. 19. Comparison of Natural Period of Structure for Five-, Seven-, and Nine-meter Spans Length Ordinary Moment Steel Frame Buildings with and without Viscoelastic Dampers.

\section{Conclusions}

This paper investigate the overall ductility factor, $\mu$, of ordinary moment resisting steel frames with and without the viscoelastic bracing system. Effect number of stories and bay lengths on the overall ductility factor have been investigated as well. The resulted ductility factors are less than typical ASCE 7-10 value assigned to such seismic force resisting system which is 3.0. It has been noticed that ductility factor decreases with increasing the number of stories for all story buildings and increased when providing the viscoelastic damping system. The results also show that elastic displacements increased by increasing the number of stories and significantly decreased when viscoelastic dampers are provided.

It has been noticed that overall ductility factors decreased as the length of spans increased and increased when viscoelastic dampers are provided. The results show that elastic displacements decreased by increasing the span length and decreased by providing viscoelastic dampers.

The resulted approximate periods were lower than the measured natural period of structures measured using ETABS for 3-, 6-, 9-, 12-, and 15-story ordinary moment steel frames. Structural natural periods of the structure are increased by increasing the number of stories and decreased when viscoelastic damping system is provided.

The resulted approximate periods are higher than measured natural period of structures measured using ETABS for 5-, 7- and 9-meter spans length for three-story ordinary moment steel frames. Structural natural periods of the structure are increased by increasing the span lengths and decreased when viscoelastic damping system is provided. 


\section{References}

[1] R. K., McGuire, "Probabilistic seismic hazard analysis: Early history," Earthquake Engineering \& Structural Dynamics, vol. 37, no. 3, pp. 329-338 (2008).

[2] J., Marko, "Influence of Damping Systems on Building Structures Subject to Seismic Effect," Journal of Structural Engineering, vol. 26, no. 13, pp. 1939-1956 (2006).

[3] A. S., Elnashai and L., Di Sarno, Fundamentals of Earthquake Engineering, Chichester, West Sussex, United Kingdom: John Wiley \& Sons Ltd (2008).

[4] D. S., Brookshire, S. E., Chang, H., Cochrane, R. A., Olson, A., Rose and J., Steenson, "Direct and Indirect Economic Losses from Earthquake Damage," Earthquake Spectra, vol. 13, no. 4, pp. 683-701 (1997).

[5] M., Pelling, The vulnerability of cities: natural disasters and social resilience, Earthscan, (2012).

[6] N., Armouti, "Effect of dampers on seismic demand of short period structures," Jordan Journal of Civil Engineering, vol. 4, no. 4, pp. 367-377 (2010).

[7] K., Dhalla and G., Winter, "Steel ductility measurements," Journal of the Structural Division, vol. 100, no. 2, pp. 427-444 (1974).

[8] R., Clough and J., Penzien, Dynamics of Structures, New York: McGraw Hill, (1993).

[9] N., Armouti, Earthquake Engineering: Theory and Implementation, 2 ed., United States of America: International Code Council, (2008).

[10] N. M. Newmark and W. J., Hall, "Procedures and Criteria for Earthquake Resist and Design," In Selected Papers By Nathan M. Newmark@sCivil Engineering Classics, pp. 829-872 (1973).

[11] T. E., Kelly, "Design Guidelines of In-Structure Damping and Energy Dissipation," Holmes Consulting Group, Wellington, New Zealand (2001).

[12] SEAOC, "Recommended lateral force requirements and tentative commentary," Structural Engineers Association of California, California (1992).

[13] S., Nagarajaiah and S., Narasimhan, "Seismic Control of Smart Base Isolated Buildings with New Semi Active Variable Damper," Earthquake Engineering and Structural Dynamics, vol. 26, no. 6, pp. 729-749 (2007).

[14] S. A., Barakat, A. I. H., Malkawi and A. S., Al-Shatnawi, "A Step Towards Evaluation of the Seismic Response Reduction Factor in
Multistorey Reinforced Concrete Frames," Natural Hazards, vol. 16, no. 1, pp. 65-80 (1997).

[15] SANZ, "New Zealand Standard Code of Practice for General Structural Design and Design Loadings for Buildings," Standards Association of New Zealand, New Zealand (1992).

[16] N., Armouti, "Effect of dampers on seismic demand of short period structures in rock sites," Jordan Journal of Civil Engineering, vol. 5, no. 2, pp. 216-228 (2011).

[17] B., Samali, and K. C. S., Kwok, "Use of Viscoelastic Dampers in Reducing Wind- and Earthquake- Induced Motion of Building Structures," Engineering Structures, vol. 17, no. 9, pp. 639-654 (1995).

[18] S. S., Tezcan and O., Uluca, "Reduction of Earthquake Response of Plane Frame Buildings by Viscoelastic Dampers," Engineering Structures, vol. 25, no. 14, pp. 1755-1761 (2003).

[19] R., Sabetahd and Y., Zandi, "Evaluation Performance of Viscoelastic Dampers in Reduction Seismic Base Shear of Structures using Nonlinear Dynamic Analysis," American Journal of Scientific Research, no. 43, pp. 58-67 (2012).

[20] N. M., Newmark and W. J., Hall, "Earthquake Spectra and Design," Earth System Dynamics, vol. 1 (1982).

[21] R., Park and T., Paulay, Reinforced Concrete Structures, New York: John Wiley \& Sons Inc., (1975).

[22] N. C., Golubka and B., Simeonov, "Computer Program for Determination of Strength and Deformability Characteristics (RESIST)," Institute of Earthquake Engineering and Engineering Seismology University, Skopje, Macedonia (1993).

[23] AISC Committee, "Specification for Structural Steel Buildings (ANSI/AISC 360-10)," American Institute of Steel Construction, Chicago-Illinois (2010).

[24] CSI Structural Analysis Program, "ETABS 2013," Computers and Structures Inc., Berkeley, California (2013).

[25] ASCE7, "Minimum Design Loads for Buildings and Other Structures," American Society of Civil Engineers, Virginia (2010).

[26] FEMA, "NEHRP Recommended Provisions for the Development of Seismic Regulations for New Buildings, Part 1 Provisions," Federal Emergency Management Agency, Washington (1997).

[27] Y., Al-Qaryouti, "Evaluating Seismic Response Modification Factor of Reinforced Concrete Frames with Viscoelastic Damping System," Thesis Submitted in Partial Fulfillment of the Requirements of the Degree of Master of Science in Civil Engineering, The University of Jordan (2014). 